hot. The Amal burner is supplied in several sizes, that for ordinary use measuring $5 \frac{1}{2} \mathrm{in}$. high and one inch across the head, and costing 12s. $6 d$.

\section{Value of Anti-Diphtheritic Serum Treatment}

The autumn issue of the Fight against Disease (22, No. 4), the quarterly journal of the Research Defence Society, contains an article by Sir Leonard Rogers showing the reduction in the suffering and the deaths of children from diphtheria during the last forty years consequent upon the use of anti-diphtheritic serum treatment. He points out that the case mortality, the most scientific test of the value of treatment, from diphtheria in the hospitals of the Metropolitan Asylums Board, has steadily fallen every year from a percentage of 30.4 in 1890-93 before serum was used, to 9.0 in $1905,7 \cdot 4$ in 1910 , and less than 4.0 in 1933, following the treatment of the disease with the serum. More striking still is the fall in mortality for laryngeal cases, from 62 per cent in 1894 to $11 \cdot 7$ in 1910. The value of the serum treatment is even more conclusively shown by its remarkable efficacy in the early stages of the disease, as compared with its comparative failure when given after the fourth day of the disease, when the toxæmia of the disease is fully developed, in accordance with what animal experiments had indicated would be the case. The case mortality per cent when treatment is commenced on the first day of the disease is only $1 \cdot 6$, on the second day it is $7 \cdot 9$, and on the third $17 \cdot 2$. As Sir Charles Martin has pointed out, "If the antitoxin (serum) were a remedy of no value, whether it was administered on the first or on the fifth day of the disease would be immaterial". Clinical evidence is no less conclusive: many doctors still living can testify to the horrors of diphtheria in young children in the pre-serum days. This is now all changed, and the young diphtheria patient if treated early with serum will rarely succumb. Sir Leonard Rogers estimates that had the pre-serum mortality from diphtheria continued since 1911, there would have been 250,000 more deaths from diphtheria than were actually recorded.

\section{Television in the United States}

THE October issue of Electronics contains an illustrated article surveying the principal systems of television which are undergoing development in the United States of America. Of the six systems reviewed, four employ a cathode ray oscillograph type of tube for both transmission and reception; while the other two employ mechanical-optical systems comprising a vibrating mirror or a rotating mirrored disc, in conjunction with a photoelectric cell for transmission and a Kerr cell for reception. All the methods are capable of transmitting scenes photographed on the standard size of cinematograph film; most of them are also suitable for the transmission of studio scenes, while some can be successfully operated on outdoor scenic material. The number of scanning lines into which the picture is dissected for transmission varies from 60 to 400 , while an average value of 240 lines is very popular.
The transmission of such a picture at the standard cinematograph rate of 24 per second requires a communication channel of the order of $1,000 \mathrm{kc} . / \mathrm{sec}$, as compared with the space of 9 or $10 \mathrm{kc} . / \mathrm{sec}$. permitted in modern sound broadcasting. Such a large band-width is considered to be essential for satisfactory picture reproduction, and this technical limitation presents one of the most serious problems to the television worker. It requires transmitting and receiving circuits of great complexity and high cost, and it would appear to limit the available wave. band for broadcast television to the ultra-short region below 10 metres. The article referred to discusses briefly the prospects of the commercial application of television in America, and expresses the opinion that in addition to the technical problems, there are other difficulties of a financial nature involved in the provision of a television programme service throughout the country.

\section{General Šrtefánik}

General Mrlan R. Šttefánik had the distinction of being almost the only Slovak man of science to attain any eminence since the time of Komensky (1592-1670). He studied in Paris, and before the War became secretary of the Observatory at Meudon and went on several French scientific missions. During the War, he was an air force officer in France, Serbia and Italy before becoming Czechoslovak Minister of National Defence in 1918. $\mathrm{He}$ was unfortunately killed when his aeroplane crashed near Bratislava as he was returning home in May 1919. Some account of his work has now been placed on record in a book recently published by Eos, Bratislava. The author, Mr. Ferdinand Písecky, was closely associated with General Stefánik during his missions in Russia and the United States, and the book is a valuable addition to Czechoslovak literature; although it deals primarily with Stefánik's War career and his political activities, occasional reference is made to his scientific work.

\section{Eskimo Studies}

A PRIZE of a gold medal and a thousand crowns has been offered by the Royal Academy of Sciences and Letters of Denmark for a study of Eskimo origins. In the statement of the conditions upon which this prize is offered for competition, it is pointed out that there are two main opposing views on the origins and ethnological affinities of the Eskimo. The older of the two theories to which reference is made derives from the views put forward by the Danish authority, J. H. Rink, in 1871, that the Eskimo were of close affinity to the Indians of North America and had originated in a comparatively restricted centre in the interior of the American continent, from which they had migrated to Alaska and afterwards spread across the northern area as far as Greenland. Later, the place of origin was defined more precisely as in the neighbourhood of Hudson Bay. The alternative theory, which it may be said is that now more generally held, is that tho Eskimo, while showing affinities with the Indians, 